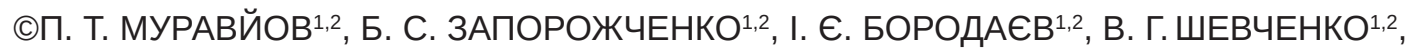 ХАРXYРI MAKPEM ${ }^{1}$
}

Одеський національний медичний університет ${ }^{1}$

кНП "Одеський обласний клінічний медичний центр" Одеської обласної ради

\section{Динаміка цитолітичного та холестатичного синдромів у хворих із захворюваннями біліопанкреатодуоденальної зони за умов різної передопераційної підготовки}

\begin{abstract}
Мета роботи: оцінити динаміку проявів цитолітичного та холестатичного синдромів у хворих із синдромом механічної жовтяниці як ускладнення вогнищевих захворювань біліопанкреатодуоденальної зони, за умов різної передопераційної підготовки. Матеріали і методи. За основу дослідженя було взято результати хірургічного лікування 272 хворих із вогнищевими захворюваннями біліопанкреатодуоденальної зони, що ускладнилися синдромом механічної жовтяниці. Всі операційні втручання виконували в обсязі панкреатодуоденальної резекції. Основну групу склали 112 пацієнтів, яким підготовку до операції і прогнозування перебігу періопераційного періоду проводили відповідно до розробленого алгоритму. У 160 пацієнтів групи порівняння підготовка до виконання операційного втручання являла собою виключно консервативну терапію.

Результати досліджень та їх обговорення. Впровадження розробленого алгоритму передопераційної підготовки привело до зменшення середніх значень аланінамінотрансферези - на 5-й день до $151 \pm 15$ Од/л в основній групі проти $188 \pm 13$ Од/л у групі порівняння. На сьомий день відмінності зберігались, набули достовірності і склали $119 \pm 12$ Од/л та $157 \pm 14$ Од/л в основній групі та в групі порівняння відповідно (p<0,05). Напередодні операції показник складав $101 \pm 11$ Од/л та $138 \pm 12$ Од/л в основній групі та групі порівняння відповідно (p<0,05). Активність аспартатамінотрансферази на 3-й день знизилася в основній групі з $204 \pm 12$ (при надходженні до стаціонару) Од/л до 153 11 Од/л, а у групі контролю - зі $186 \pm 14$ Од/л (при надходженні до стаціонару) до $161 \pm 9$ Од/л. Різниця між порівнюваними групами стала суттєвою та почала набувати достовірність 3 5-ї доби $124 \pm 13$ Од/л проти $150 \pm 11$ Од/л в основній та групі порівняння відповідно (p<0,05). Напередодні виконання панкреатодуоденальної резекції різниця

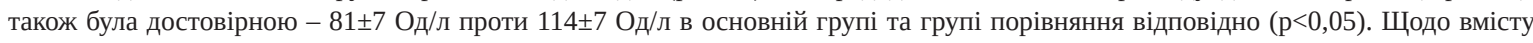

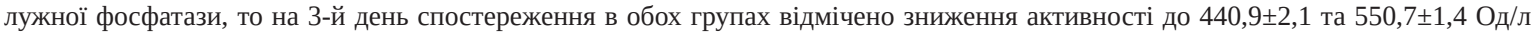
$(\mathrm{p}<0,05)$. На 5-й день спостереження значення показнику були ще меншими, причому в основній групі відбулося більш значу-

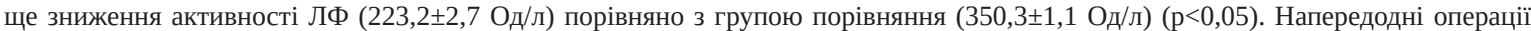

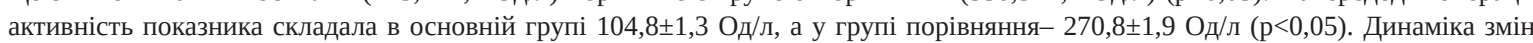
активності ү-глутамілтрансферази на 3-й день дослідження значення показника в основній групі та групі порівняння зменшилися

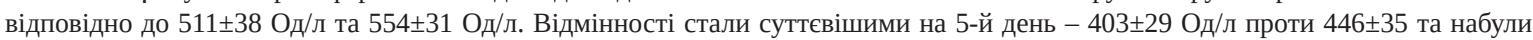
достовірності на 7-й день - 304 21 Од/л проти $374 \pm 26$ Од/л в основній групі та групі порівняння відповідно (р<0,05). Напередодні хірургічного втручання подальше зниження показника зберегло свою достовірність $271 \pm 29$ Од/л в основній групі проти $348 \pm 33$ Од/л у групі порівняння ( $<0,05)$.
\end{abstract}

Ключові слова: механічна жовтяниця; біліарне дренування; панкреатодуоденальна резекція; хронічний псевдотуморозний панкреатит; рак головки підшлункової залози.

Постановка проблеми і аналіз останніх досліджень та публікацій. Одними $з$ найпоширеніших причин розвитку механічної жовтяниці у досліджуваних хворих треба вказати такі, як хронічний псевдотуморозний панкреатит (ХПТП), рак головки підшлункової залози (ПЗ), рак Фатерова соска, рак дистального відділу холедоха [1-4].

Перебіг післяопераційного періоду у хворих, яким було виконано радикальне операційне втручання в обсязі панкреатодуоденальної резекції (ПДР) на висоті холемії більш ніж в 50 \% випадків, супроводжується різними ускладненнями, а в деяких випадках взагалі призводить до летального результату [5-8].

Все вищенаведене не тільки підкреслює актуальність та пояснює дискутабельність дослідної проблеми, а й спонукає до подальших пошуків можливих варіантів її вирішення.

Мета роботи: оцінити динаміку проявів цитолітичного та холестатичного синдромів у хворих на вогнищеві захворювання біліопанкреатодуоденальної зони, ускладнені синдромом механічної жовтяниці, за умов різної передопераційної підготовки.

Матеріали і методи. В основу цього дослідження покладено аналіз результатів хірургічного лікування 272 хворих, яким було виконано панкреатодуоденальну резекцію (ПДР). Основним показанням до її виконання були злоякісні новоутворення панкреатобіліарної зони (218 хворих) i хронічний псевдотуморозний панкреатит (ХПТП) (54 пацієнта), перебіг яких був ускладнений механічною жовтяницею. Осіб чоловічої статі було 59 


\section{З ДОСВІДУ РОБОТИ}

(52,7 \%) в основній і $82(51,3 \%)$ в групі порівняння, жіночої, відповідно, 53 (47,3 \%) і 78 (48,7 \%). Спостерігали приблизно однаковий середній вік пацієнтів у рандомізованих когортах, а саме $49,6 \pm 4,1$ i 47,3 $\pm 3,3$ року в основній групі і в групі порівняння відповідно. Діагностичний алгоритм, окрім загальноклінічних, складався із загальноприйнятих лабораторних та інструментальних методів дослідження.

Результати досліджень та їх обговорення. В основі розподілу хворих на дві групи лежав певний вид передопераційної підготовки: в основній групі (112 пацієнтів) підготовка до операції і прогнозування перебігу післяопераційного періоду проводилися відповідно до розробленого алгоритму; в групі порівняння (160 пацієнтів), підготовка відповідала загальноприйнятим правилами (табл. 1).

У більшості хворих тяжкість стану визначалась виразністю та тривалістю холемії і початковими проявами синдрому поліорганної недостатності. Більшість дослідних хворих отримували спеціалізовану допомогу лише на 7-10 добу, а деякі взагалі через місяць після прояву жовтяниці.

Після математичного моделювання ризику виконання панкреатодуоденальної резекції з урахуванням патоморфологічних параметрів стану хворого та визначення належності хворого до певного фенотипу за виявленими генними мутаціями приймали рішення щодо подальшого лікування (патент України № 128782; опубл. 10.10.2018; Бюл. № 19). В тому випадку, коли індекс ризику розвитку ускладнень виходив за межи референтних значень, лікування розпочинали 3 шунтуючого декомпресійного втручання на жовчовивідних шляхах (основна група, 112 (41,2 \%) хворих). Якщо ж індекс ризику не перевищував 60, вдавалися до виконання панкреатодуоденальної резекції.

У 112 хворих основної групи як передопераційну підготовку було застосовано власнорозроблений метод експрес-детоксикації (патент України № 130491; опубл. 10.12.2018; Бюл. № 23). Його суть полягала в проведенні мініінвазивного шунтуючого втручання на жовчовивідних шляхах катетерами 6F або 9F поряд із виконанням плазмаферезу кількістю від 2 до 6 сеансів та пероральним призначеням спеціально підібраного фармкомплексу. Декомпресію вважали ефективною за умов декременту показників цитолітичного синдрому в 20-25 \% від попередньої доби при об’ємній швидкості виділення жовчі по дренажу 60-100 мл / доб, але не швидше 300 мл/доб.

Мініінвазивні шунтуючі втручання на жовчоивідних протоках у вигляді пункційних та лапароскопічно асистованих біліарних декомпресій було виконано у 112 (41,2 \%) хворих основної групи. Черезшкірній черезпечінковій холангіостомії (ЧШЧПХС) надавали перевагу - виконали у 44 (39,3 \%) хворих. До лапароскопічної (ЛХ) (37 (33,0 \%) хворих) або пункційної (ПХ) УЗ-контрольованої (31 (27,7 \%) хворих) холецистостомії вдавалися при виникненні технічних складнощів через варіабельну анатомію судинного русла печінки (табл. 2).

При оцінці динаміки активності АлАТ за умов різної передопераційної підготовки встановлено,

Таблиця 1. Розподіл хворих залежно від виду передопераційної підготовки

\begin{tabular}{||l|c|c||}
\hline \multirow{2}{*}{\multicolumn{1}{|c|}{ Причина біліарної обструкції }} & \multicolumn{2}{|c||}{ Кількість хворих } \\
\cline { 2 - 3 } & основна група, n=112 (\%) & група порівняння, n=160 (\%) \\
\hline Рак головки підшлункової залози (174) & $81(72,3)$ & $93(58,1)$ \\
\hline Рак Фатерова соска (20) & $12(10,7)$ & $8(5,0)$ \\
\hline Рак дистального відділу гепатикохоледоху (24) & $8(7,1)$ & $16(10,0)$ \\
\hline Хронічний псевдотуморозний панкреатит (54) & $11(9,8)$ & $43(26,9)$ \\
\hline
\end{tabular}

Таблиця 2. Методи біліарної декомпресії

\begin{tabular}{||l|c||}
\hline \multicolumn{1}{|c|}{ Метод втручання } & Кількість хворих, n= 112 (\%) \\
\hline Черезшкірна черезпечінкова холангіостомія & $44(39,3)$ \\
\hline Лапароскопічна холецистостомія & $37(33,0)$ \\
\hline Пункційна холецистостомія & $31(27,7)$ \\
\hline
\end{tabular}




\section{З ДОСВІДУ РОБОТИ}

що на 3-й день вона знизилася у хворих основної групи з 294 17 Од/л (при надходженні до стаціонару) до $223 \pm 14$ Од/л, тоді як в групі порівняння з 281 16 Од/л (при надходженні до стаціонару) до $247 \pm 17$ Од/л. На 5-й день середні значення зменшилися до $151 \pm 15$ Од/л в основній групі проти $188 \pm 13$ Од/л у групі порівняння. На сьомий день відмінності зберігались, набули достовірності і склали $119 \pm 12$ Од/л та $157 \pm 14$ Од/л в основній групі та в групі порівняння відповідно $(\mathrm{p}<0,05)$.

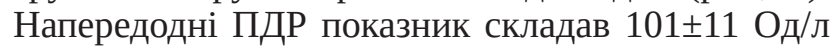
та 138 \pm 12 Од/л в основній групі та групі порівняння відповідно $(\mathrm{p}<0,05)$, що можна розцінити як доказ більшої ефективності запропонованого нами підходу до передопераційної підготовки (рис. 1).
Внаслідок застосування превентивних заходів вираження цитолітичного синдрому зменшувалося. Так, на 3-й день активність ферменту АсАт зни-

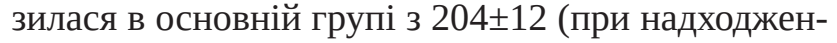
ні до стаціонару) Од/л до $153 \pm 11$ Од/л, а у групі контролю - зі $186 \pm 14$ Од/л (при надходженні до

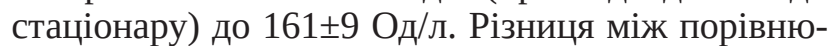
ваними групами стала суттєвою та почала набувати достовірність з 5-ї доби $124 \pm 13$ Од/л проти $150 \pm 11$ Од/л в основній та групі порівняння відповідно ( $<0,05)$. Напередодні виконання операційного втручання (ПДР) різниця між показниками

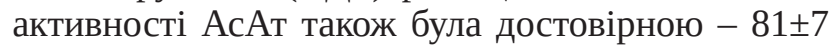
Од/л проти $114 \pm 7$ Од/л в основній групі та групі порівняння, відповідно (р<0,05) (рис. 2).

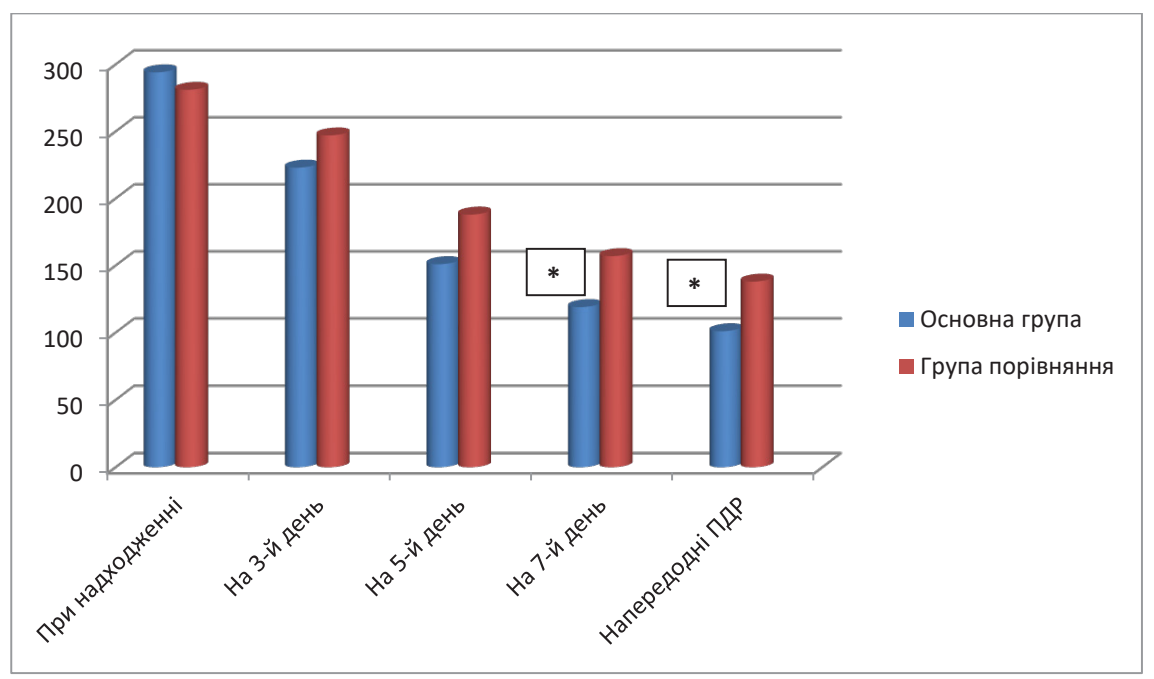

Рис. 1. Динаміка вмісту аланінамінотрансферази у пацієнтів різних клінічних груп.

Примітка: *-p<0,05; за віссю ординат надано рівень АлАТ, за віссю абсцис - час від моменту госпіталізації.

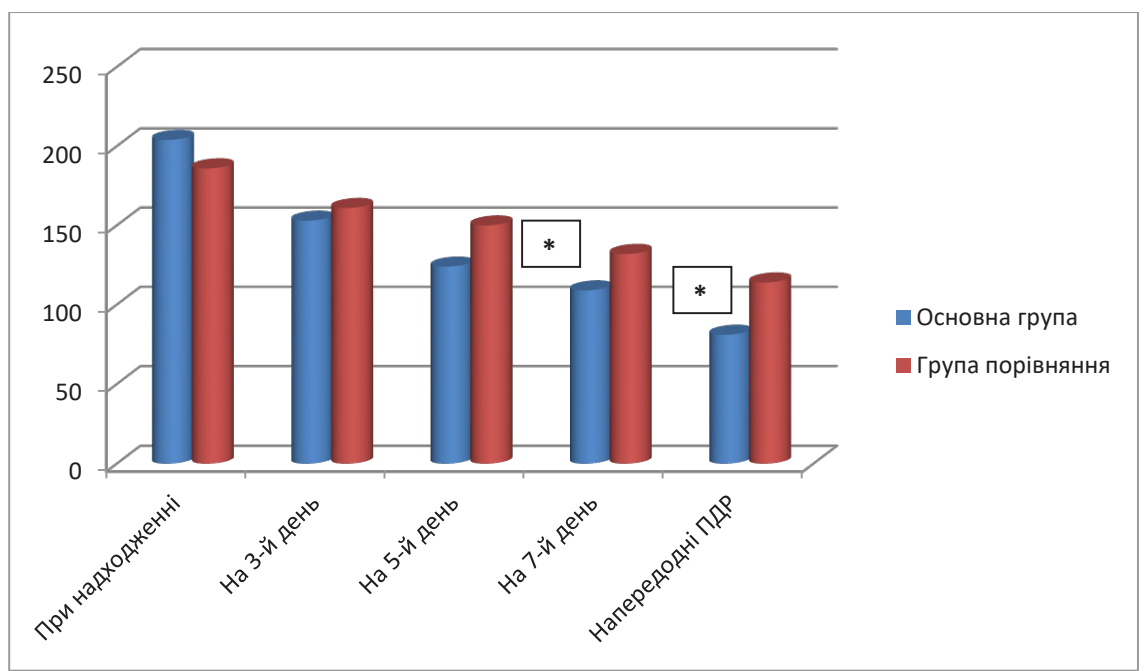

Рис. 2. Динаміка вмісту аспартатамінотрансферази в пацієнтів різних клінічних груп.

Примітка: *-p<0,05; за віссю ординат надано рівень АсАТ, за віссю абсцис - час від моменту госпіталізації. 


\section{З ДОСВІДУ РОБОТИ}

Щодо динаміки ү-глутамілтрансферази, то цей показник дещо відрізнявся від інших трансаміназ (рис. 3). На початку дослідження активність ү-глутамілтрансферази (ГГТ) склала в середньому $673 \pm 28$ Од/л у групі порівняння та 669 41 Од/л - в основній групі. На 3-й день дослідження значення показника в основній групі та групі порівняння зменшилися, відповідно, до 511 38 Од/л та $554 \pm 31$ Од/л. Відмінності стали більш суттєвими

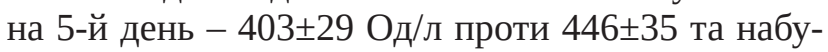
ли достовірності на 7-й день - 304 \pm 21 Од/л проти $374 \pm 26$ Од/л в основній групі та групі порівняння відповідно $(\mathrm{p}<0,05)$. Напередодні ПДР подальше зниження показника зберегло свою достовірність
$271 \pm 29$ Од/л в основній групі проти 348 \pm 33 Од/л у групі порівняння $(\mathrm{p}<0,05)$.

У коливаннях активності лужної фосфатази (ЛФ) також було встановлено певні особливості залежно від виду передопераційної підготовки (рис. 4). На 3-й день спостереження вміст ЛФ в обох

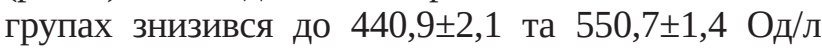
$(\mathrm{p}<0,05)$. На 5-й день спостереження значення показнику були ще меншими, причому в основній групі відбулося більш значуще зниження активності ЛФ (223,2 22,7 Од/л) порівняно з групою порівняння $(350,3 \pm 1,1$ Од/л) (p<0,05). Напередодні ПДР активність ЛФ складала в основній групі 104,8 1 1,3 Од/л, а у групі порівняння $-270,8 \pm 1,9$ Од/л $(\mathrm{p}<0,05)$.

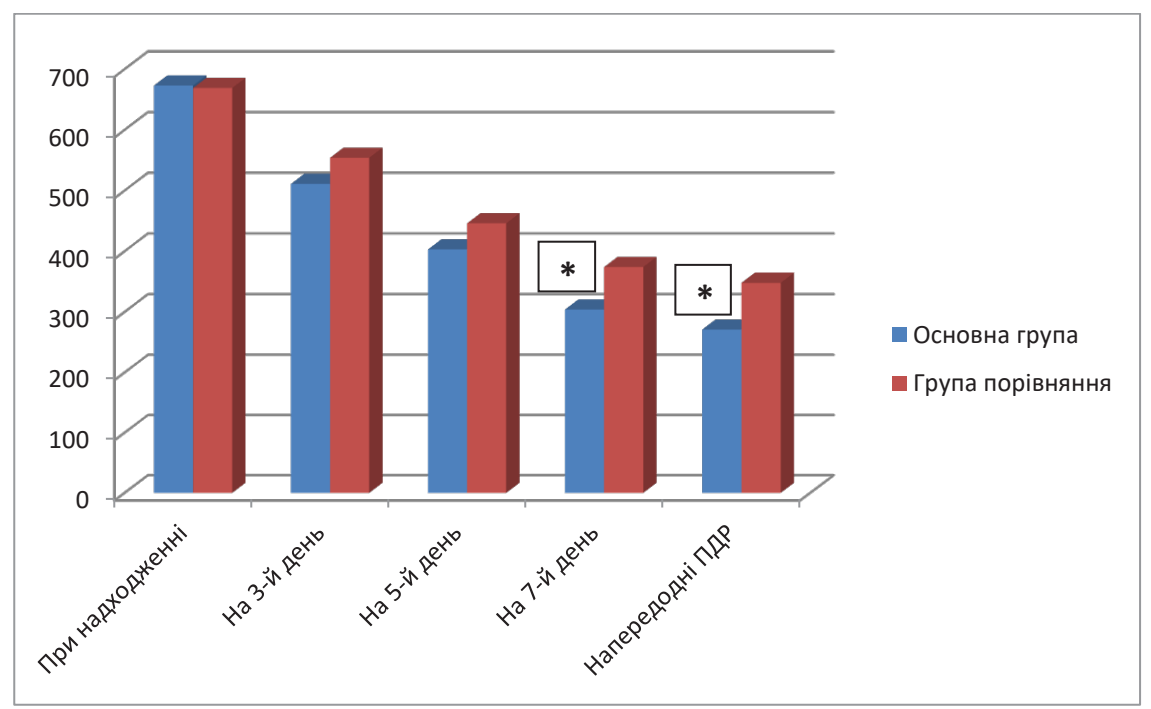

Рис. 3. Динаміка вмісту глутамілтрансферази у пацієнтів різних клінічних груп.

Примітка: * - p<0,05; за віссю ординат надано рівень ГГТ, за віссю абсцис - час від моменту госпіталізації.

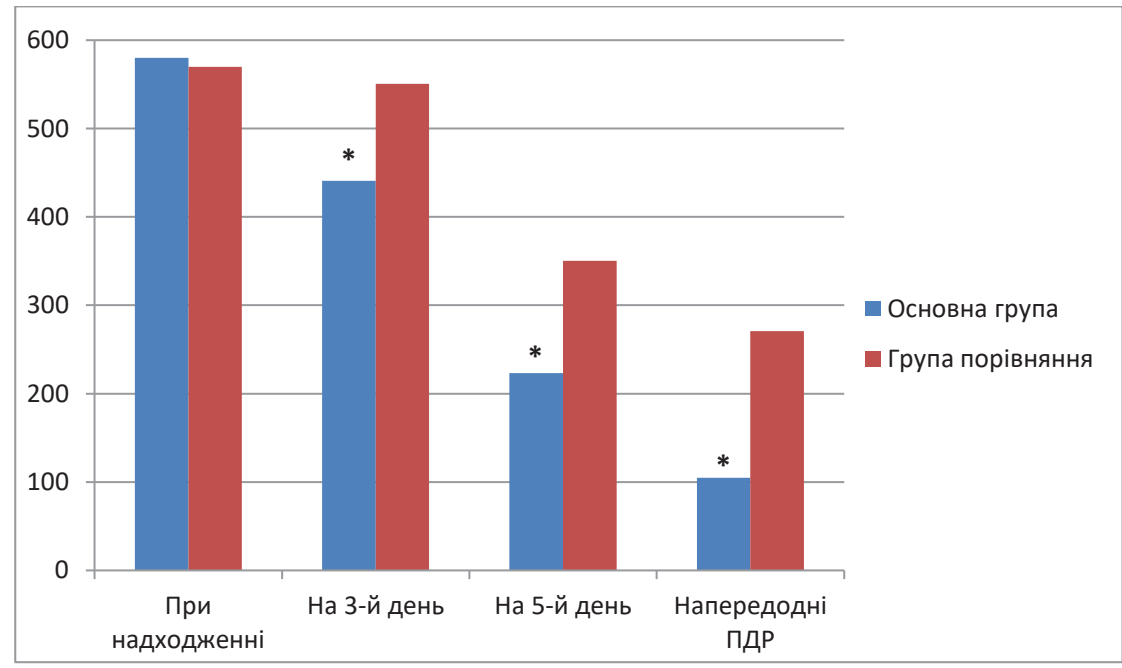

Рис. 4. Динаміка активності лужної фосфатази у пацієнтів різних клінічних груп.

Примітка: * $-\mathrm{p}<0,05$. 


\section{З ДОСВІДУ РОБОТИ}

За рахунок впровадження розробленого алгоритму детоксикації із застосуванням мініінвазивних шунтуючих втручань на жовчовивідних шляхах у хворих основної групи вже на третій день вдалося досягти суттєвого зниження рівня білірубінемії до 185,1 22,4 мкмоль/л. На п’ятий день рівень білірубінемії сягнув 163,2 22,6 мкмоль/л і

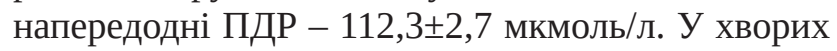

групи порівняння за умов передопераційної підготовки до ПДР лише шляхом консервативної терапії зниження білірубінемії було не таким суттєвим. На третій день передопераційної підготовки його вдалося знизити лише до 258,4 $\pm 2,9$ мкмоль/л, на пятий - до 222,2士3,8 мкмоль/л. Напередодні ПДР показник білірубінемії склав 198,3 $\pm 3,3$ мкмоль/л (рис. 5).

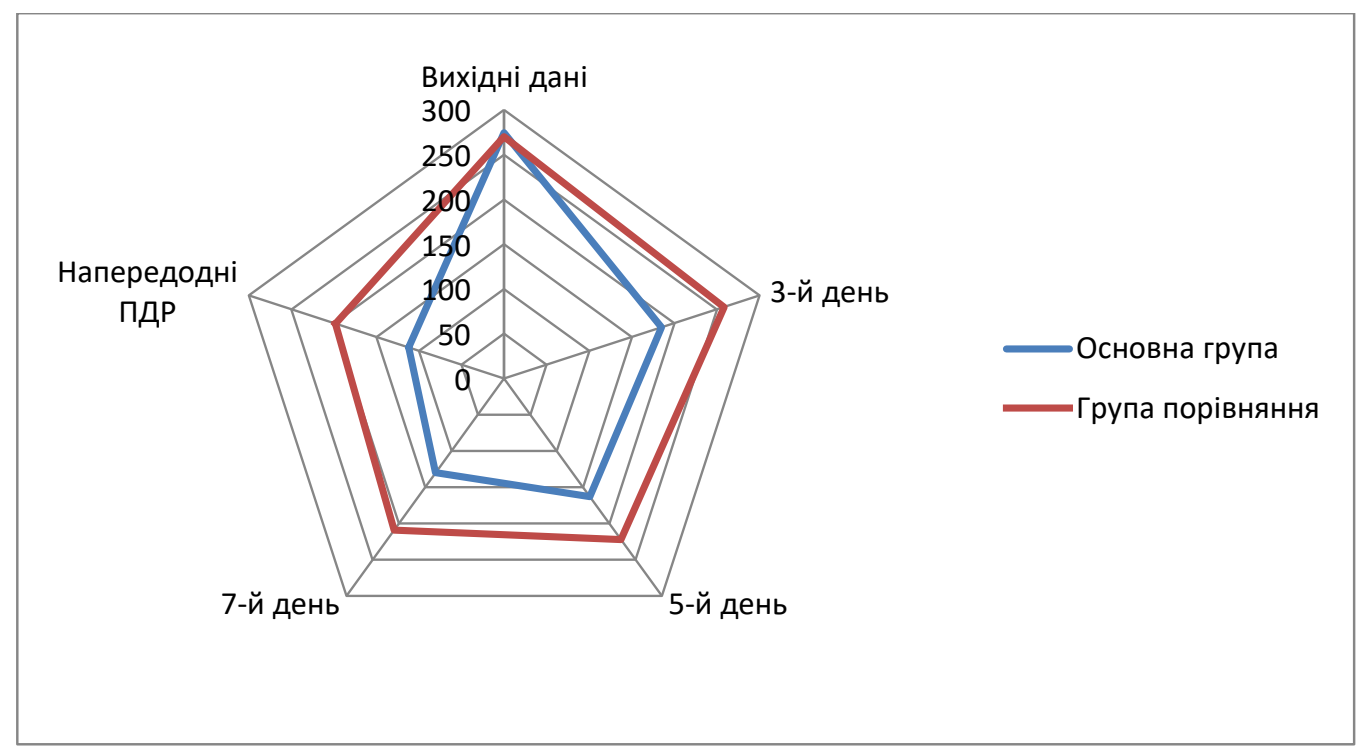

Рис. 5. Динаміка загального білірубіну в групах спостереження.

При сумації випадків виникнення загрозливих для життя післяопераційних ускладнень у клінічних групах встановлено, що їх кількість в основній групі склала $42(37,5 \%)$ випадки, а у групі порівняння - 102 (63,8 \%) випадки. Таким чином за частотою післяопераційних ускладнень група порівняння значно випереджала основну $\left(\mathrm{x}^{2}=18,22\right.$ $\mathrm{df}=1 \mathrm{p}<0,0001)$ (табл. 3).

В основній групі померло 7 (6,3 \%) хворих, тоді як в групі порівняння -19 (11,9\%).
Висновки. Таким чином, завдяки розробленому алгоритму передопераційної підготовки у хворих основної групи вдалося досягти кращих динамічних змін показників цитолітичного та холестатичного синдромів - більш значущих та достовірних порівняно із хворими групи порівняння, що дало змогу більш якісно підготувати хворих до виконання панкреатодуоденальної резекції і знизити кількість виникнення загрозливих для життя післяопераційних ускладнень на 26,3% (p<0,0001).

Таблиця 3. Розподіл загрозливих для життя післяопераційних ускладнень згідно з класифікацією Clavien-Dindo

\begin{tabular}{||l|c|c||}
\hline \multicolumn{1}{|c|}{ Градація ускладнень } & Основна група, $\mathrm{n}=112(\%)$ & Група порівняння, $\mathrm{n}=160$ (\%) \\
\hline Grade IIIa & $11(9,8)$ & $22(14,4)$ \\
\hline Grade IIIb & $12(10,7)$ & $38(6,3)$ \\
\hline Grade IV & $12(9,8)$ & $19(11,9)$ \\
\hline Grade V & $7(6,3)$ & $102(63,8)$ \\
\hline Всього & $42(37,5)$ & $22,8)$ \\
\hline
\end{tabular}




\section{З ДОСВІДУ РОБОТИ}

Перспективи подальших досліджень. Отримані результати створюють досить суттєве підгрунтя для продовження досліджень в заданому напрямку. Адже кількість хворих на рак біліопанкреатодуоденальної зони, як і на хронічний панкреатит, з року в рік продовжує невпинно зростати, а іншого за обсягом радикального операційно-

\section{СПИСОК ЛІТЕРАТУРИ}

1. Elbanna K. Y. Imaging diagnosis and staging of pancreatic ductal adenocarcinoma: a comprehensive review / K. Y. Elbanna, H. J. Jang, T. K. Kim. // Insights Imaging. - 2020 - Vol. 11 (1). - P. 58.

2. Pancreaticoduodenectomy and outcomes for groove pancreatitis / F. Aguilera, L. Tsamalaidze, M. Raimondo [et al.] // Dig. Surg. - 2018. - Vol. 35 (6). - P. 475-481.

3. Современные аспекты хирургического лечения синдрома механической желтухи / В. Ю. Михайличенко, В.В.Кисляков, А. М. Резниченко [и др.] // Современные проблемы науки и образования. - 2019. - № 3. - С. 78-83.

4. Каніковський О. Є. Алгоритм хірургічного лікування ускладнених форм хронічного панкреатиту / О. Є. Каніковський, I. В. Павлик, I. В. Олійник // Медичні перспективи. - 2018. - T. 23, № 4. - С. 79-84.

5. Preoperative therapy and pancreatoduodenectomy for pancreatic ductal adenocarcinoma: a 25-year single-institution experi-

\section{REFERENCES}

1. Elbanna, K.Y., Jang, H.J., \& Kim, T.K. (2020). Imaging diagnosis and staging of pancreatic ductal adenocarcinoma: a comprehensive review. Insights Imaging, 11 (1), 58. DOI: https://doi. org/10.1186/s13244-020-00861-y.

2. Aguilera F., Tsamalaidze, L., \& Raimondo M. (2018). Pancreaticoduodenectomy and outcomes for groove pancreatitis. Dig. Surg., 35 (6), 475-481. DOI: 10.1159/000485849.

3. Mihajlichenko, V.Ju., Kisljakov, V.V., \& Reznichenko, A.M. (2019). Sovremennye aspekty hirurgicheskogo lecheniya sindroma mehanicheskoy zheltuhi [Modern aspects of the mechanical jaundice syndrome surgical treatment]. Sovremennye problemy nauki i obrazovaniya - Modern Aspects of Science and Education, 3, 78- 83 [in Russian].

4. Kanikovskyi, O.Ye., Pavlyk, I.V., \& Oliinyk, I.V. (2018). Alhorytm khirurhichnoho likuvannia uskladnenykh form khronichnoho pankreatytu [Algorithm of complicated chronic pancreatitis surgical treatment]. Medychni perspektyvy - Medical Perspectives, 23, 4, 79-84 [in Ukrainian].

5. Cloyd, J.M., Katz, M.H.G., \& Prakash, L. (2017). Preope- го втручання, як панкреатодуоденальна резекція, поки що не впроваджено. Отже, пошук заходів, спрямованих на покращення безпосередніх результатів єдиного за радикальністю операційного втручання, $є$ перспективним напрямком сучасної хірургічної панкреатолоії. ence / J. M. Cloyd, M. G. Katz, L. Prakash [et al.] // J. Gastrointest. Surg. - 2017. - Vol. 21 (1). - P. 164-174.

6. Pancreatoduodenectomy at the Verona Pancreas Institute: the evolution of indications, surgical techniques and outcomes: a retrospective analysis of 3000 consecutive cases / C. Bassi, G. Marchegiani, T. Giuliani [et al.] // Ann. Surg. - 2021. DOI: 10.1097/ sla.0000000000004753.

7. Randomized trial of pylorus-preserving vs. pylorus-resecting pancreatoduodenectomy: long-term morbidity and quality of life / U. Klaiber, P. Probst, F. J. Hüttner [et al.] // J. Gastrointest. Surg. - 2020. - Vol. 24 (2). - P. 341-352.

8. Mortality and postoperative complications after different types of surgical reconstruction following pancreaticoduodenectomy a systematic review with meta-analysis / S. Schorn, I. E. Demir, T. Vogel [et al.] // Langenbecks Arch Surg. - 2019. - Vol. 404 (2). - P. 141-157. rative therapy and pancreatoduodenectomy for pancreatic ductal adenocarcinoma: a 25-year single-institution experience. J. Gastrointest. Surg., 21 (1), 164-174. DOI: https://doi.org/10.1007/ s11605-016-3265-1.

6. Bassi, C., Marchegiani, G., \& Giuliani, T. (2021). Pancreatoduodenectomy at the Verona Pancreas Institute: the evolution of indications, surgical techniques and outcomes: a retrospective analysis of 3000 consecutive cases. Ann. Surg., DOI: 10.1097/ sla.0000000000004753.

7. Klaiber, U., Probst, P., \& Hüttner, F.J. (2020). Randomized trial of pylorus-preserving vs. pylorus-resecting pancreatoduodenectomy: long-term morbidity and quality of life. J. Gastrointest Surg., 24 (2), 341-352. DOI: 10.1007/s11605-018-04102-y.

8. Schorn, S., Demir, I.E., Vogel, T., Schirren, R., Reim, D., Wilhelm, D., ..., \& Ceyhan, G.O. (2019). Mortality and postoperative complications after different types of surgical reconstruction following pancreaticoduodenectomy - a systematic review with meta-analysis. Langenbecks Arch. Surg., 404 (2), 141-157. DOI: 10.1007/s00423-019-01762-5. 


\section{DYNAMICS OF CYTOLYTIC AND CHOLESTATIC SYNDROMES IN PATIENTS WITH DISEASES OF THE BILIOPANCREATODUODENAL AREA UNDER CONDITIONS OF DIFFERENT PREOPERATIVE PREPARATION}

The aim of the work: to evaluate the dynamics of manifestations of cytolytic and cholestatic syndromes in patients with focal diseases of the biliopancreatoduodenal area complicated by the syndrome of mechanical jaundice, under conditions of different preoperative preparation.

Materials and Methods. The results of surgical treatment of 272 patients who underwent pancreatoduodenal resection in various modifications for focal diseases of the biliopancreatoduodenal area complicated by the development of obstructive jaundice syndrome were analyzed. The main group included 112 patients, who were prepared for surgery and predicted the course of the postoperative period according to the developed algorithm. The comparison group included 160 patients, who were prepared only in a conservative way.

Results and Discussion. Due to the application of the developed algorithm of preoperative preparation, the average values of alanine aminotransferase on the 5th day decreased to $(151 \pm 15) \mathrm{U} / \mathrm{l}$ in the main group against (188 \pm 13$) \mathrm{U} / \mathrm{l}$ in the comparison group. On the seventh

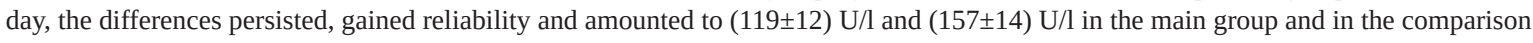
group, respectively $(\mathrm{p}<0.05)$. On the eve of the operation, the indicator was $(101 \pm 11) \mathrm{U} / \mathrm{l}$ and $(138 \pm 12) \mathrm{U} / \mathrm{l}$ in the main group and the comparison group, respectively $(\mathrm{p}<0.05)$. Aspartate aminotransferase activity on the 3rd day decreased in the main group from (204 \pm 12$)$ (on

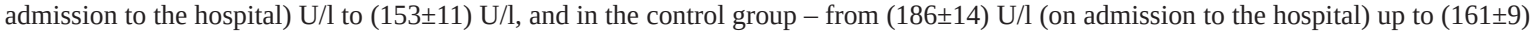
U/l. The difference between the compared groups became significant and began to gain reliability from the 5 th day (124 \pm 13 ) U/l against $(150 \pm 11) \mathrm{U} / \mathrm{l}$ in the main and comparison groups, respectively $(\mathrm{p}<0.05)$. On the eve of pancreatoduodenal resection, the difference was also significant $-(81 \pm 7) \mathrm{U} / \mathrm{l}$ against $(114 \pm 7) \mathrm{U} / \mathrm{l}$ in the main group and the comparison group, respectively (p<0.05). Regarding the content of alkaline phosphatase, on the 3rd day of observation in both groups there was a decrease in activity to (440.9 \pm 2.1$)$ and (550.7 \pm 1.4$)$ U/l $(\mathrm{p}<0.05)$. On the 5 th day of observation, the values of the indicator were even smaller, and in the main group there was a more significant decrease in its activity (223.2 \pm 2.7$) \mathrm{U} / \mathrm{l}$ compared with the comparison group (350.3 \pm 1.1$) \mathrm{U} / \mathrm{l}(\mathrm{p}<0.05)$. Finally, on the eve of the operation, the activity of the indicator was $(104.8 \pm 1.3) \mathrm{U} / \mathrm{l}$ in the main group, and $(270.8 \pm 1.9) \mathrm{U} / \mathrm{l}$ in the comparison group (p<0.05). Dynamics of changes in activity of $\gamma$-glutamyltransferase on the 3rd day of the study, the values of the indicator in the main group and the comparison

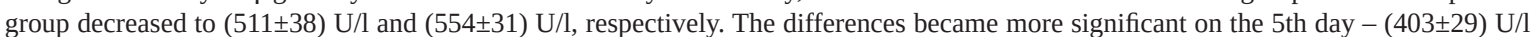
against (446 \pm 35 ), and became significant on the 7th day - (304 \pm 21$) \mathrm{U} / \mathrm{l}$ against (374 \pm 26$) \mathrm{U} / \mathrm{l}$ in the main group and the comparison group, respectively $(\mathrm{p}<0.05)$. On the eve of surgery, a further decrease in the indicator retained its reliability (271 \pm 29$) \mathrm{U} / \mathrm{l}$ in the main group against (348 \pm 33$) \mathrm{U} / \mathrm{l}$ in the comparison group $(\mathrm{p}<0.05)$.

Key words: obstructive jaundice; biliary drainage; pancreatoduodenal resection; chronic pancreatitis; pancreatic cancer. 